\title{
ASPECTOS POLÍTICOS DA PARRESÍA EM FOUCAULT
}

\author{
Thiago Rêgo Alves ${ }^{1}$
}

RESUMO: A parresía, entendida como dizer tudo, dizer verdadeiro, ou fala franca, foi o último objeto de estudo do filósofo Michel Foucault. Foucault encontra a parresía ao analisar a sexualidade na Antiguidade grega, mais precisamente na relação entre mestre e discípulo, e como um termo característico da estrutura política da pólis ateniense. Porém, esse termo político vai sendo configurado por Foucault de modo conflitante com a estrutura democrática. O presente artigo analisa os aspectos políticos da parresía em Foucault de modo a elucidar os estudos desse filósofo sob os referidos aspectos. Vemos Foucault percorrer um caminho teórico que coloca o dizer verdadeiro como atividade privilegiada da Filosofia sem, com isso, excluir a dimensão política que lhe confere.

PALAVRAS-CHAVE: Parresía; Dizer Verdadeiro; Estrutura Política.

ABSTRACT: The parresía, understood as to mean everything, to say the true, or to frankly, was the last study from the philosopher Michel Foucault. Foucault finds parresía when analyzing sexuality in ancient Greece, specifically the relationship between master and disciple, and as a political structure from Athenian pólis. But this political term will be 
set by Foucault as conflicting with the democratic structure. This article analyzes the political aspects of Foucault's parresia in order to elucidate this philosopher's studies in these aspects. We see Foucault travel through a theoretical path that puts the true speech as an activity privileged of Philosophy without, however, exclude the political dimension.

KEYWORDS: Parresía; True Speech; Political Structure. 


\section{INTRODUÇÃO}

Foucault inicia seus estudos sobre subjetividade e verdade em 1982, no curso Hermenêutica do sujeito. Nesse curso o filósofo analisa os modos pelos quais o indivíduo, na Antiguidade grega, poderia estabelecer uma relação com determinados códigos de conduta de modo a tornar-se sujeito de suas práticas, o que se daria por meio da ascese, de permanentes exercícios e cuidados para consigo no cotidiano. E são nessas técnicas de si que o filósofo encontrou o termo paraskeué, que concernia a exercícios praticados com o objetivo de transformar os discursos em atos ${ }^{2}$, uma atitude moral que exigiria “a conjugação do comportamento verbal ao comportamento de vida"3; e, ainda referente ao cuidado de si, como uma específica relação com o outro, precisamente na relação entre mestre e discípulo, o dizer verdadeiro surgia como um indispensável mecanismo na condução da alma deste último por seu mestre. Esta teria sido a "primeira grande análise da parresía"4 feita por Foucault 5 .

Ao considerar seu estudo sobre a parresía, em 1984, Foucault menciona que sua intenção era encontrar o "tipo de ato pelo qual o sujeito, dizendo a verdade, se manifesta, [...] representa a si mesmo e é reconhecido pelos outros como dizendo a verdade" . Porém, esse "dizer a verdade" não passaria por critérios que definiriam o discurso como verdadeiro ou falso (ninguém questionará se o que está sendo dito é ou não verdade). A intenção do filósofo com esse estudo era alcançar o que ele chamou de aleturgia ${ }^{7}$, em suma, a maneira pela qual a verdade é manifestada.

É dessa forma que Foucault se dedica à análise da parresía, elucidando nos escritos antigos (textos de Eurípedes, 
Tucídides, Isócrates, Platão e Aristóteles) ${ }^{8}$ as circunstâncias em que o dizer verdadeiro era proferido. Vemos aqui a parresía surgir na estrutura política de Atenas como um direito de nascimento concedido pela democracia e como certa forma de exercer o poder. Em seguida, em ambientes não democráticos, em especial o monárquico, com a análise de textos de Platão. O filósofo dedica grande parte do curso de 1983 ao entendimento do dizer verdadeiro na filosofia.

\section{PARRESÍA: DEMOCRACIA E PRIVILÉGIO}

Foucault cuida de entender a ligação entre o dizer verdadeiro e a organização da pólis ateniense. Na obra Íon, de Eurípedes seu protagonista homônimo é filho do deus Apolo com Creusa, filha de Erecteu, um dos semeadores da cultura de Atenas. Íon é abandonado em uma caverna por Creusa e resgatado por Hermes a pedido de Apolo, que o deixa na porta de Delfos onde é criado por uma sacerdotisa de Apolo sem conhecimento de sua origem. Xuto, descendente de Aqueus e marido de Creusa, decide ir com esta a Delfos para saber do oráculo se terão filhos.

Quando é revelado a Xuto que seu filho será “o primeiro que vir" quando sair do templo, ele encontra Íon e diz ser o seu pai ${ }^{9}$. Ion pergunta, por sua vez, quem seria a sua mãe, pois "eis tò prôton zugòn (para a primeira fileira)" 10 de cidadãos seria preciso ser filho de autóctones, portanto, se Xuto não era, restaria perguntar por sua mãe, “hós moi génetai metróthen parresía' [para que eu herde a parresía do lado materno; acresce Foucault]" ${ }^{11}$. Esse é o ponto que notamos em 
Foucault sobre o Íon ${ }^{12}$ : a parresía é um privilégio de quem é nascido em Atenas e é um modo de exercer o poder pelo dizer verdadeiro, portanto, não diz respeito a qualquer cidadão estando relacionada ao exercício do poder político.

Entretanto, Foucault encontra em um escrito de Políbio (livro II de Histórias) a parresía como terceira característica da estrutura política dos Aqueus, depois da demokratia (participação dos cidadãos), e da isegoria (igualdade de direito e de dever para todos os cidadãos), a parresía surge como a "liberdade para os cidadãos de tomar a palavra [...] tanto do ponto de vista abstrato (a atividade política) como de uma forma bem concreta: na assembleia"13. Portanto, para haver democracia seria preciso haver parresía, bem como o contrário, já que o livre falar estava ligado à igualdade de direito e dever, e à participação dos cidadãos. O filósofo estabelece essa relação ainda no Íon, onde era preciso a parresía para que se tivesse acesso à democracia, dizendo de outro modo no contexto, era preciso saber de onde era a mãe para que se pudesse aceder à "primeira fileira" de cidadãos, logo, para Foucault, o que estava em questão era a liderança da cidade com suas implicações, ou seja, o ódio "do povo, o ódio dos adýnatoi (impotentes); a zombaria dos sophoí (dos sábios); e, enfim, a rivalidade e a inveja dos que se ocupam da cidade" ${ }^{14}$. Porém, quando se coloca isegoria e parresía como condições para a democracia compromete-se a dynasteía (ascendência, exercício do poder) pelo dizer verdadeiro, pois, pelo que estamos vendo no estudo do filósofo em questão, ter direito à parresía significava alçar-se à "primeira fileira" da cidade, pertencer à categoria específica de cidadãos que manejam tanto o lógos quanto a pólis, algo que o direito de todos a falar parecia contradizer. 
Segundo Foucault, o dizer verdadeiro tem seu lugar "definido e garantido pela politeía"15, ou seja, pela constituição da cidade, motivo de sua análise do Hipólito, em que, devido a uma falta moral cometida por sua madrasta ${ }^{16}$, Hipólito perde o direito de exercer a parresía, ainda que não tenha perdido com isso sua cidadania. Foucault destaca a qualificação pessoal no exercício do dizer verdadeiro, acrescentando, porém, que "o dizer a verdade do político é aquilo porque vai ser assegurado o jogo conveniente da política" ${ }^{17}$, dizendo de outro modo: há o jogo da política (interesses) porque há o jogo da verdade. Como ocorre em Orestes, em que seu protagonista homônimo mata a mulher que traiu seu pai (Agamêmnon) e, após ser capturado é submetido a um julgamento em que é pedida a palavra da multidão (a assembleia é o plano de fundo) que lá está sobre o seu destino. Segundo Foucault, o primeiro que se ergue para falar é um antigo companheiro do pai de Orestes, Taltíbio, personagem homérico que "o texto diz simplesmente que suas palavras são dikhómyta" ${ }^{18}$, que o filósofo traduz por dúplices e conclui dessa forma que teria sido um discurso, que de algum modo agradasse a todos (lisonja); o segundo a falar é o rei Diomedes, herói homérico que pede o exílio de Orestes; o terceiro é um cidadão que "na grosseria da sua parresía, suficientemente persuasivo para conduzir os cidadãos a algum desastre"19, pede a execução de Orestes; já o quarto cidadão que teria sido descrito como autourgós andreîos (lavrador corajoso) disse:

Para Orestes, filho de Agamêmnon, eu peço uma coroa [...], porque ele quis vingar seu pai, matando uma mulher culpada e ímpia que tirava dos homens gloriosos o desejo de armar seu braço e fazer campanha fora de casa ${ }^{20}$. 
Orestes é executado. O que chama a atenção do filósofo é o julgamento ter acontecido em uma assembleia e a palavra ter sido concedida a todos presentes. Foucault faz uma dissociação entre o que chamou de má e boa parresía aqui. A má parresía seria esta do Orestes, em que qualquer um tem direito à palavra sem que antes sejam observadas as qualidades pessoais daquele que fala e, ainda, esse discurso é feito sem riscos, não denuncia nada. Nesse sentido da denúncia, o discurso do cidadão que pede para Orestes ser coroado seria o que Foucault chamou de boa parresía, pois se coloca contra a opinião corrente (a de que Orestes tem que pagar por um crime), ainda que se faça em um meio em que a palavra é concedida a todos e sua ascendência pessoal esteja ligada à lavoura, o que Foucault entende como uma origem pobre e, portanto, não pertencente a cidadãos que ocupam a primeira fileira.

Com isso, o que o filósofo pergunta é: Como a democracia poderia suportar o dizer verdadeiro? Ele encontra um notável exemplo do bom uso do dizer verdadeiro na democracia em A guerra do Peloponeso, de Tucídides, mais precisamente em discursos de Péricles (495 a. C./429 a. C.) que governou Atenas em parte do referido conflito (que foi de 431 a 404 a. C.). No contexto desse primeiro discurso, os lacedemônios (habitantes da região Peloponeso) decretam que Atenas ceda parte de seu território para que não ocorra um conflito, é então que os atenienses se reúnem em assembleia para decidir o que fazer. Depois de muitos falarem e se pronunciarem tanto contra quanto a favor do conflito, "Péricles, filho de Xântipos, o homem mais eminente entre os atenienses daquele tempo graças à sua superioridade tanto em palavras quanto em atos" ${ }^{\prime 1}$, toma a palavra: 
Mantenho-me fiel ao meu pensamento de sempre, atenienses: não devemos ceder aos peloponésios. Ainda agora vejo que devo dar-vos o mesmo conselho do passado, ou quase o mesmo, e espero, por uma questão de justiça, que aqueles que nos apoiarem se mantenham corresponsáveis pela decisão no caso de falharmos, ou então não aspirem, no caso de sucesso, às honras de uma decisão inteligente. Os acontecimentos podem moverse tão imprevistamente, com efeito, quanto os planos dos homens; é por isso que em geral pomos na sorte a culpa de todos os acontecimentos contrários ao nosso raciocínio.

Notamos aqui as características da boa parresía anteriormente descritas: a ascendência daquele que fala (qualidade pessoal) e a denúncia, nessa circunstância, do risco do conflito, onde aqueles que concordam em não ceder as terras atenienses compartilharão da vitória ou da derrota, pedido contrário feito àqueles que não concordam com o confronto. Além disso, Foucault nota a coexistência da politeía $^{22}$, ou seja, da organização democrática em que todos têm direito de falar, com a boa parresía. Os atenienses decidem pelo conflito.

No outro discurso de Péricles, Atenas encontra-se sem recursos e com baixo efetivo devido a doenças. A população está revoltada contra seu governante, que lhes aconselhou o caminho da guerra. Péricles convoca uma assembleia para discorrer sobre, onde diz:

Ao convocar esta assembleia, meu propósito foi fazervos relembrar certos fatos e advertir-vos quanto à 
vossa atitude injustificada, seja demonstrando o vosso rancor contra mim, seja deixando-vos abater por vossas desventuras. [...] Se a cidade pode suportar o infortúnio de seus habitantes na vida privada, mas o indivíduo não pode resistir aos dela, todos certamente devem defendêla, em vez de agir como fazeis agora propondo o sacrifício da segurança da comunidade por estar desesperados com as dificuldades que enfrentais internamente e adotando uma atitude crítica tanto em relação a mim, por vos haver aconselhado a entrar na guerra, quanto a vós mesmos, que votastes comigo a favor dela ${ }^{23}$.

Segundo Foucault, essa atitude de Péricles é coerente com uso da boa parresía por ele feito, algo coerente quando o pacto $^{24}$ formado pelo dizer verdadeiro é quebrado. Péricles, em um primeiro momento, deixou claro sua opinião e os perigos de quem o apoiasse nessa opinião, porém, insatisfeitos com as desventuras, os cidadãos se voltaram contra ele, culpando-o por toda situação, uma atitude injustificada haja visto o pacto parresiástico estabelecido entre governante e governados.

Dessa forma, Foucault conclui que para haver democracia é necessária a livre tomada de palavra (isegoria), mas que seria indispensável para esta politeía o dizer verdadeiro, pois de outro modo a organização democrática estaria ameaçada, como, por exemplo, no período após a queda de Péricles, em Discurso sobre a paz (cerca de 350 a. C.) de Isócrates, em que este se dirige à assembleia dizendo saber que o direito à palavra não é o mesmo para todos: "Não é nada surpreendente, pois tendes sempre o costume de expulsar todos os que não falam no sentido de vossos desejos" 25 . Foucault pergunta pela dynasteía, quem poderá adquirir ascendência onde não lhe permitem 
falar? Assim, o filósofo afirma que "a liberdade de palavra é um problema político" ${ }^{26}$, portanto, não apenas do regime democrático, mas também de aristocráticos e autocráticos, pois diz respeito à condução das almas das pessoas, nas palavras de Foucault, diz respeito a uma psicagogia, "um ato político" 27.

Foucault dá seguimento analisando a parresía nos textos de Platão e notando, a partir dessas análises, a vida do filósofo Antigo como um lugar privilegiado para manifestação do dizer verdadeiro, não que o dizer verdadeiro deixe de ser notado na democracia ou em textos que tivessem como plano de fundo qualquer outra organização política, mas Foucault vai criando critérios do que de fato seria a parresía, dando maior visibilidade a uma noção específica do termo. Passemos à parresía filosófica.

\section{A PARRESÍA FILOSÓFICA}

Foucault lembra que a melhor cidade para Platão é fundada numa relação ideal com a verdade, não havendo problema com isso. Foucault pergunta se seria melhor, no caso de uma cidade indexada à verdade: conceder a palavra a todos para que possam se expressar (democracia) ou "confiar na sabedoria de um Príncipe que seria esclarecido por um bom conselheiro?"28 $\mathrm{O}$ filósofo lembra que a democracia, em A república, surge por meio da tomada de poder dos oligarcas (os que possuem dynasteía) pelos pobres:

[...] A democracia surge, penso eu, quando após a vitória dos pobres, estes matam uns, expulsam outros, e partilham 
igualmente com os que restam o governo e as magistraturas, e esses cargos são, na maior parte, tirados à sorte. - É essa, efetivamente, a maneira como se estabelece a democracia, quer pelas armas, quer pelo medo do outro partido, o que foge $e^{29}$.

Por meio da guerra a politeía seria dividida entre os vencedores reinando a liberdade para se dizer e fazer o que quiser $^{30}$. Para Platão, na democracia cada indivíduo poderia "escolher a modalidade que lhe aprouver, como se chegasse a uma feira de constituições e pusesse em prática aquela que tivesse selecionado" ${ }^{31}$. Foucault observa que a parresía para Platão não é tratada como elemento de integração, mas como um meio por onde cada indivíduo escolherá suas leis para se orientar na cidade, faltando aos indivíduos a referência da verdade. Se na oligarquia essa referência é dada pelos homens de ascendência que estão no governo e na democracia essa referência é inviabilizada pela livre palavra, na monarquia essa referência seria possível graças à figura do filósofo e do conselheiro do Príncipe. Nesse sentido, Foucault analisa as cartas $V$, VII e VIII de Platão, por tratarem de tal questão.

Na carta $V$, Platão teria enviado um discípulo, Eufraio, a Perdicas, irmão do Imperador Felipe, da Macedônia, como conselheiro. Platão diz "conhecer o que é vantajoso para a democracia, no entanto, sendo-lhe facultado falar ao povo e dar-lhe conselhos, nunca se levantou para dirigir-lhes uma só palavra" ${ }^{32}$, segundo ele, por ter nascido tarde demais e sua pátria o considerar um caso perdido. Foucault atenta para a seguinte passagem: "cada forma de governo tem uma linguagem própria, como se dá com certos animais; a democracia fala 
de um jeito, como a oligarquia ou a monarquia, de maneira

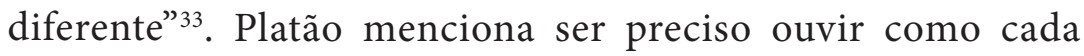
politeía se expressa, e diz ainda saber o que é vantajoso para a democracia, portanto, ele ouviu o que o Estado precisava ainda que não quisessem ouvi-lo (exemplo de má parresía). Segundo Foucault, a função do filósofo na politeía seria "formular, articular o que se diz em um Estado de tal maneira que o que nele se diz, seja efetivamente conforme ao que é, em sua natureza, o Estado"34; assim, o filósofo é colocado como aquele capaz de conhecer a natureza da politeía e melhor orientá-la.

A carta VII fala de um investimento político feito diretamente por Platão, suas viagens à Sicília. Platão foi por três vezes à Sicília, a primeira por razões particulares onde conheceu Dion, cunhado de Dionísio, o Velho, monarca da Sicília. Platão ensinou filosofia a Dion tendo se surpreendido por seu interesse, tornando-se seu amigo. Em sua segunda viagem, Platão foi convidado por Dion para "servir de conselheiro político e, ao mesmo tempo, pedagogo de Dionísio, o Moço, filho de Dionísio, o Velho, herdeiro do poder" 35 . Assim, Platão partiu para Siracusa, no entanto, quando lá chegou só encontrou discórdia, Dion foi acusado de conspirar contra a tirania de Dionísio que, por sua vez, exilou Dion ${ }^{36}$. Platão voltou para Atenas e, algum tempo depois recebeu o pedido de Dionísio para retornar e instruí-lo em filosofia, Dionísio prometeu repatriar Dion caso Platão retornasse, este vai então pela terceira vez, tratando de entender as intenções de Dionísio quanto à filosofia, porém, notando um desinteresse pela vida filosófica em Dionísio, além de novos desentendimentos entre Dion e Dionísio, Platão regressa a Atenas. Dion assume o 
poder, porém é assassinado por grupos ligados a Dionísio. A família de Dion escreve a Platão pedindo que intervenha no conflito entre os dois grupos, e é então quando Platão escreve a carta VII, avaliando sua relação com a política.

Platão inicia a carta falando de sua decepção em relação à política, desde a aristocracia dos $\operatorname{Trinta}^{37}$, em que ele e Sócrates foram obrigados a levar "à força um cidadão para ser executado" ${ }^{38}$, até a ascensão da democracia, em que Sócrates foi condenado a morte. Porém, diz Platão, "não desanimei de encontrar remédio para esse estado de coisas, sempre à espera da situação oportuna para poder agir" ${ }^{39}$. Foucault aponta esses dois fatores como motivos para Platão se omitir da participação política: a falta de amigos (phíloi) e a falta de situação oportuna (kaíroi); tendo encontrado no convite de Dion, seu amigo, uma situação oportuna, ao que Dion teria dito para seu convencimento nunca ter havido uma situação como aquela de "concretizar-se nos mesmos homens [os familiares de Dionísio, o Moço] a união da filosofia e do governo das cidades" 40 . Platão levou isso em consideração, pois, para ele, era o momento de

pôr em prática meus projetos de legislação e de governo. Bastava persuadir um único homem para que tudo me saísse bem. [...] Envergonho-me diante de mim mesmo a só ideia de passar por charlatão incapaz de realizar nada concreto e de trair tão cedo a hospitalidade e a amizade de Dião ${ }^{41}$.

Foucault atenta para este trecho: "me envergonhava por passar perante mim mesmo como um verbo vazio (mè dóxaimí pote emautô pantápasi logos mónon atekhnôs eînai) que 
nunca quer pôr mãos à obra (érgon dè oudenòs án pote hekòn anthápsasthai)" ${ }^{22}$; mais precisamente pelo jogo de palavras lógos e érgon, Platão temia ficar apenas no lógos, mas qual o modo de passar ao érgon? Por meio do aconselhamento ${ }^{43}$, da instrução do soberano, mediante a parresía daquele encarregado de ouvir (referência à carta V) a politeía, como "quem tivesse de aconselhar a algum doente submetido a dieta prejudicial à saúde, [...] mudar seu regime" 44 . O discurso do filósofo se faz necessário na politeía quando algo nela encontra-se fora de lugar, o filósofo seria consultado como um médico que trataria de dizer que caminhos tomar.

No livro IV de As leis, é feita uma distinção entre a medicina para escravos e a medicina para as pessoas livres: a primeira seria caracterizada pela prescrição de medicamentos com base na experiência, como se o médico "detivesse o conhecimento exato, e com a autossuficiência de um monarca despótico" ${ }^{35}$; enquanto a segunda seria caracterizada por médicos que conversam "com o próprio paciente e com seus amigos, podendo assim obter conhecimento a partir daquele que padece da doença [e seus amigos] como transmitir a estes as devidas impressões na medida do possível" ${ }^{\prime 6}$. Desse modo, a medicina que ouve o paciente seria a boa medicina, aquela que de fato cura quando se é atacado por uma enfermidade, pois "o mesmo se verifica com as cidades, quer sejam dirigidas por um homem apenas, quer por muitos" ${ }^{47}$. Mas em que sentido seria o aconselhamento do filósofo? Segundo Platão, seria no sentido do funcionamento das instituições e do poder soberano devendo prevalecer o desenvolvimento da politeía, sendo necessária a disposição para ouvir os conselhos do filósofo (sem o coagir em favor de interesses específicos) e a 
fazer o melhor pela cidade ${ }^{48}$ de modo que, enfatiza Foucault, não é a função da filosofia dizer a verdade sobre a política, "não é nem mesmo ditar imperiosamente o que deve ser tanto a constituição das cidades, como a política ou o governo" 49 .

Em suma, Foucault observa em Platão de que maneira o filósofo pode passar do discurso à obra, que é por meio do aconselhamento político, do diagnóstico dos problemas do Estado, não se tratando esse diagnóstico da função da filosofia, mas da maneira pela qual o seu lógos pode incidir no mundo como érgon. Mas por que o filósofo e não qualquer outro? Porque o lógos do filósofo estaria indexado à natureza das coisas e, portanto, à verdade, e não a uma dissimulação como o discurso retórico, que procura o convencimento do falso como verdadeiro ${ }^{50}$, ou à lisonja, que consiste em perceber o que pensa o ouvinte, formular um discurso a partir desse pensamento, "e restituí-lo ao ouvinte que fica com isso tanto mais facilmente convencido e tanto mais facilmente seduzido por ser o que ele diz" ${ }^{11}$. O discurso filosófico estaria baseado, nas palavras de Foucault, em uma homologia (característica da parresía entre mestre e discípulo) em que há uma aparente identidade entre os discursos ${ }^{52}$, de modo que diferenças como ascendência pessoal ou autoridade real não são levadas em consideração, o que pode facilmente ser entendido como critério de verdade da parresía filosófica, por excluir fatores de ordem social que possam influenciar no discurso, motivo este de Foucault insistir no risco [até de morte] para quem fala como uma característica da parresía, ainda que Platão renuncie a esse risco aconselhando o filósofo ao mesmo ${ }^{53}$. Porém, se a parresía filosófica exclui a ascendência pessoal dos interlocutores, a parresía política (a das assembleias) 
seria, então, menos verdadeira? Foucault conclui dizendo que a filosofia é o lugar por excelência do que chamou de boa parresía e que aquele discurso de Péricles, em vez de vincular "mestre e discípulo na unidade do ser" ${ }^{4}$, como fazia Sócrates estabelecendo uma homologia de modo que o discurso parresiástico pudesse conduzir a alma do outro (psicagogia) à verdade, "vinculava a pluralidade dos cidadãos reunidos na cidade à unidade de comando do que assume a ascendência sobre eles" 55 , o que conduziria a uma retórica, já que a unidade da cidade seria estabelecida pela palavra (Foucault chama apenas de comando) daquele que está à frente dos demais (primeira fileira) de modo que seu discurso prevalecesse sobre os demais, pois se trataria de convencer, persuadir "na forma dessa superioridade [ascendência] afirmada" ${ }^{5}$. Portanto, apenas o discurso filosófico seria adequado ao bom uso da parresía, enquanto o discurso político seria apenas um discurso retórico.

É assim que a filosofia seria um lugar privilegiado dessa manifestação da verdade configurada por Foucault, ainda que, como vimos em Orestes, por exemplo, a parresía possa ser manifestada por um cidadão sem ascendência pessoal em uma assembleia. No entanto, devemos mencionar um último ponto acerca disso. Quando Platão decidiu acatar o pedido de Dionísio, que disse estar interessado em aprender filosofia, e foi à Siracusa pela terceira vez, ele mencionou ter tratado logo de saber se Dionísio estava de fato interessado em filosofia ${ }^{57}$ por um meio, segundo ele, elegante e aplicável aos tiranos:

Para gente desse estofo é preciso mostrar toda a extensão dos estudos filosóficos, sua natureza, as dificuldades 
muito próprias e quanto esforço exigem de nós. [...] Se for dotado de natureza divina, além de revelar vocação para tais estudos, ficará maravilhado com o caminho apontado e no mesmo instante se decidirá a enveredar por ele e não viver de outra maneira. Ao depois, avançando resolutamente e arrastando consigo o próprio guia, não se deterá antes de atingir a meta que se impôs ou de adquirir a capacidade necessária para conduzirse sem o auxílio de ninguém. É nesse estado de espírito que tal homem vive; e até mesmo nas ocupações mais triviais, a todo instante e em quaisquer circunstâncias não se despega da filosofia, daquele gênero de vida que o deixara com o espírito sóbrio e capaz de aprender, boa memória e raciocínio lesto ${ }^{58}$.

Foucault destaca o trecho: "[...] É preciso mostrar o que é tò prâgma (o que é essa coisa, a própria coisa); através de que atividades práticas se exerce (di hóson pragmáton); e que trabalho ela implica e supõe (kaì hóson pónon ékhei)" 59 . Segundo o filósofo, a palavra prâgma tem dois sentidos no grego, referente (aplicado a um termo ou preposição), sentido encontrado no primeiro trecho: "É preciso mostrar a eles pân tò prâgma: o real da filosofia" ${ }^{0}$. O segundo sentido é o da palavra pragmáton que seria o mesmo que prágmata: atividade, negócio, exercício, prática; portanto, um sentido que não diz respeito a um termo ou preposição, mas a práticas que seriam a realidade da filosofia, e que práticas em específico seriam essas? Foucault categoriza dizendo serem essas práticas um caminho a trilhar, o caminho da vida filosófica, em que o indivíduo teria de se esforçar voltando sua vida para tal caminho onde, ainda que tenha a alma guiada por um mestre, 
conduziria a si mesmo, o que implicaria uma mudança em suas ações cotidianas e renúncias de hábitos desenvolvendo com isso três habilidades: eumathés, melhor aprendizado; mnémon, melhor memória; e logízesthai dunatòs, melhor raciocínio, melhor decisão. Um caminho que trabalha o próprio indivíduo, "um trabalho de si sobre si" ${ }^{61}$ é, segundo Foucault, a realidade da filosofia, meio pelo qual o filósofo constitui seu éthos dando testemunho da verdade pela maneira como vive:

A vida filosófica é uma manifestação da verdade. Ela é um testemunho. Pelo tipo de existência que se leva, pelo conjunto de opções que se faz, pelas coisas que você renuncia, pelas que aceita, pela maneira que você se veste, pela maneira como fala, etc., a vida filosófica deve ser, de ponta a ponta, a manifestação da verdade ${ }^{62}$.

Desse modo, a filosofia da Antiguidade é caracterizada por Foucault como uma manifestação da verdade pelo éthos do filósofo. Foucault menciona mais duas características da mesma, a direção do dizer verdadeiro aos que governam e a predicação dos indivíduos, respectivamente: o já mencionado conselho ou educação do Príncipe; e a escola de Epicteto, em que havia aulas de filosofia para quem queria tornar-se filósofo ou para quem queria apenas uma consulta.

\section{DIFERENCIAÇÃO ÉTICA}

Desse modo, Foucault vai salientar o que chamou, de modo esquemático, de a reversão platônica e a hesitação aristotélica, o que faz para melhor compreender a relação 
parresía/democracia em Platão e Aristóteles. O primeiro diz respeito à necessidade de uma politeía (constituição) basearse na verdade, embora a parresía, o dizer verdadeiro corajoso, não possa existir na democracia de outra forma, a menos como referência. O que ocorre na metáfora do barco, em que os oradores demagogos tentam tomar o leme (que, no regime democrático, pertence ao povo) por meio de lisonjas ao governante, este sendo, por sua vez, no mito da caverna, aquele que contempla a verdade, aquele que "ainda que tenha reconhecido nela a sua pátria [vai] ter que voltar à cidade e se tornar um dos que a governam"63. Para Foucault, é esse o modo que Platão encontra de relacionar a parresía e o bom governo, Platão "reverte" a noção de que não se pode haver parresía no regime democrático por conta do "indiscernimento" entre verdadeiro e falso, dizendo que há sim a verdade, porém ela é apenas uma referência para o governante, devendo este "se basear em um discurso verdadeiro que banirá democratas e demagogos" ${ }^{64}$. Portanto, o bom governo não diz respeito à democracia na reversão platônica.

E, por fim, a hesitação aristotélica, que também insiste em relacionar bom governo e parresía, porém, por meio de um questionamento da escansão menos numerosos e numerosos, ou seja, do questionamento da separação governo da maioria, governo da minoria e governo de um só, como determinantes para as caracterizar, respectivamente, democracia, aristocracia e monarquia. Aristóteles, no livro III da Política, menciona que o poder do Estado é caracterizado segundo sua concentração: nas mãos de um só homem, nas mãos de uma minoria e nas mãos de uma maioria. Entretanto, para Aristóteles, o que caracterizaria a democracia não seria 
o poder nas mãos da maioria ${ }^{65}$, mas o poder nas mãos dos pobres e em função dos pobres, ainda que estes fossem a minoria, assim como o que caracterizaria a oligarquia seria o poder nas mãos dos ricos e em função dos ricos, mesmo que estes fossem a maioria, sendo democracia e oligarquia consequências negativas, respectivamente, da politeí $a^{66}$ e da aristocracia, por privilegiarem seus segmentos sociais (pobres ou ricos) em detrimento do bem comum.

É assim, observa Foucault, que Aristóteles hesita em relação a um princípio bem arranjado nos demais filósofos que trabalharam esse tema, colocando em questão a respectiva relação ricos e pobres/menos numerosos e numerosos. Além disso, Aristóteles põe em questão quem seriam "os melhores", pois não havendo um homem virtuoso em todos os aspectos da sua vida ${ }^{67}$, o que impediria este homem de agir conforme o bem da cidade ainda que fosse pobre? Dessa forma, Aristóteles coloca em jogo três dos princípios anteriormente enumerados por Foucault, o da escansão (a diferença entre numerosos e menos numerosos como fator determinante), do isomorfismo (pertencer a um grupo menos numeroso não implica dizer que é bom) e o da transitividade (pertencer a um grupo menos numeroso não implica procurar o bem da cidade), pois, para Aristóteles, independente da "forma de governo, os que governam podem governar em seu interesse ou no interesse da cidade" 68 .

É a essa possibilidade que Foucault chama de diferenciação ética, a possibilidade de trabalhar no éthos do indivíduo uma maneira de agir que possa beneficiar um bom governo. Porém, como destaca Foucault, para Aristóteles a diferenciação ética não é válida em todos os regimes políticos, constata-se isso 
na dissociação que Aristóteles faz entre realeza, aristocracia e politeía: realeza seria a monarquia "que visa ao interesse comum"69; aristocracia, "a forma de governo por poucos (mas sempre mais do que um) seja porque governam os melhores ou porque se propõe o melhor para a cidade e seus membros"70; e politeía seria "quando muitos governam em vista ao interesse comum"71. Aristóteles enfatiza que essa forma de governo de muitos em favor do bem comum recebe um nome genérico (em relação aos demais regimes) por ser "possível para um, ou poucos, distinguir-se pela excelência; mas dificilmente [para] um maior número de cidadãos"72.

Foucault avalia essa análise de Aristóteles notando que todas as formas de regime político anteriormente citadas apontam tanto para a possibilidade de um governo em benefício próprio, quanto para um governo voltado para o bem comum, mas apenas no governo de muitos, essa diferenciação ética é bastante difícil. Nas palavras do filósofo:

Quando a gente se dirige a uma massa de pessoas, mesmo que essas pessoas governem a cidade, não é possível, ou é muito difícil encontrar nelas essa diferenciação ética, essa demarcação ética, essa singularidade ética a partir da qual dizer a verdade será possível e, nesse dizer a verdade, o interesse da cidade reconhecido [...]. Não tem nome [a designação genérica] porque, verossimilmente, não tem existência concreta [...], não pode ter existência real porque, numa democracia, a diferenciação ética não funciona ${ }^{73}$.

Segundo Foucault, o problema de Aristóteles foi tentar encontrar um modo pelo qual a diferenciação ética pudesse 
ser compreendida em termos de "governo democrático", o que pareceu chocar-se contra a estrutura política democrática e por ela ser sufocada, essa apreciação do éthos pelo dizer verdadeiro.

O problema da parresía política seria, portanto, o modo de estruturação do governo, motivo pelo qual Foucault retoma a carta VII de Platão para esclarecer duas questões, a primeira: Por que o investimento de Platão foi um fracasso? Lembremos: Platão foi à Sicília por amizade a Dion (a quem havia conhecido e percebido um apreço por seus ensinamentos) e porque tratava de convencer uma única pessoa para dar um direcionamento adequado à cidade. Logo, Platão foi à Sicília com o objetivo de educar Dionísio, o que não ocorreu em nenhuma das vezes em que se atreveu a ir.

A segunda questão pela qual Foucault retoma a carta VII: Por que Platão fracassou? Para Foucault, Platão fracassou devido a "suas impressões sobre Dion e a uma má natureza de Dionísio, às intrigas deste com Dion, [e] finalmente, mais tarde, ao assassinato de Dion" ${ }^{\prime 4}$. Platão fez a segunda viagem à Siracusa por afeição a Dion e para educar Dionísio, mencionando ter aguentado de tudo pelo propósito que o havia levado até lá: "Porém, sua renitência [de Dionísio] anulou todos os meus esforços"75. E na terceira investida a Siracusa, Platão se disse motivado pelos "insistentes chamados de Dionísio"76, que disse estar interessado em filosofia, ainda que Platão tenha logo constatado que não era verdadeiro tal interesse $^{77}$. Foucault, ao tomar conhecimento desses relatos de Platão, atribui o fracasso deste à conjuntura histórica e não à estrutura política, ou, dizendo de outro modo, o fracasso de Platão ocorreu devido às circunstâncias e não ao modo de organização do sistema político: a monarquia. 
É na monarquia que o dizer verdadeiro torna-se realizável, na possibilidade de mudar o direcionamento de uma só pessoa e, assim, de toda a cidade, como no Discurso II, de Isócrates, em que este fala a Nicoclés, filho do tirano Euágoras, rei de Salamina, que acaba de morrer. Isócrates se dirige a Nicoclés por meio de um discurso escrito, algum tempo após a posse deste, dizendo-o possuir um presente que nenhum cortesão pode dar, um presente que raramente é concedido a um rei, desde o momento em que assume o poder, e que só adquire valor com o uso:

Os homens de condição privada têm numerosas oportunidades de aprender sobre os seus deveres. Os reis, que exercem a mais difícil missão na terra, não têm praticamente nenhuma oportunidade de fazer o mesmo. [...] Quanto a mim, pensei que, se eu pudesse definir corretamente os deveres de que deve cuidar e os atos de que deve abster-se para governar sabiamente Salamis e seu reino, estaria dando-lhe a prenda mais bela, mais útil, a que mais convém eu oferecer e você aceitar ${ }^{78}$.

O que esse dizer verdadeiro poderia produzir no governante? Uma diferenciação ética que poderia torná-lo mais cuidadoso em relação a suas atitudes, que poderia leválo a educar-se melhor e, assim, a um bom governo, a um modo de agir diferenciado em benefício da comunidade, isso porque a parresía está ligada ao éthos do indivíduo, é "porque o éthos do Príncipe é o princípio e a matriz do seu governo que a parresía é possível, preciosa, útil, no caso do governo autocrático"79, enquanto no governo democrático as condições de desenvolvimento do éthos são reduzidas, mas em ambos 
(monarquia e democracia) "o éthos é o vínculo, o ponto de articulação entre o dizer a verdade e o bem governar" ${ }^{80}$.

Assim, destacamos três considerações: a parresía não surge mais como um direito dos cidadãos, mas como uma prática que tem como aplicação primeira não a cidade, mas a psykhé do indivíduo, havendo desse modo a passagem "da pólis à psykhé como correlativo essencial da parresía" 81; a segunda consideração concerne ao objetivo parresiástico que, agora voltado para a psykhé, vai procurar mudar o comportamento do(s) indivíduo(s), "o objetivo do dizer a verdade é, portanto, menos a salvação da cidade do que o éthos do indivíduo" "22; e, por fim, como consequência, a parresía toma forma agora em um "conjunto de operações que permitem que a veridicção induza na alma efeitos de transformação" ${ }^{33}$, sendo o escopo dessa transformação, o governo dos outros.

\section{CONCLUSÃO}

O que fizemos foi acompanhar o estudo de Foucault sobre a parresía nas principais estruturas políticas atenienses, na democracia e na autocracia, como privilégio e exercício de poder, além de uma certa redução da noção do dizer verdadeiro, configurado por Foucault, ao filósofo, onde o filósofo estaria mais apto a exercer o que chamou de parresía por ignorar qualquer ascendência ou diferenciação social, características essas da parresía grega (visto em Péricles, por exemplo) que Foucault então se distancia. O filósofo segue a análise dos textos antigos e vai constatando a dificuldade da democracia em suportar o dizer verdadeiro, destacando que o 
que inviabilizaria essa noção específica de parresía na estrutura democrática, seria exatamente a dificuldade de se desenvolver o éthos em um grande número de pessoas, tanto em Platão, em que a verdade aparece como referência a ser seguida pelo filósofo governante, quanto em Aristóteles, em que a parresía é possível na realeza (monarquia) e na aristocracia, pelo pouco número de pessoas envolvidas no governo, de modo que onde houvesse um bom governo, haveria um éthos bem constituído e uma relação fundamental com o dizer verdadeiro.

\section{NOTAS}

${ }^{1}$ Mestrando em Filosofia pela Universidade Federal do Piauí (UFPI). E-mail: naupaz@hotmail.com.

${ }^{2}$ FOUCAULT, 2006, p. 390: O que Foucault chamou de discursos "adquiridos em sua materialidade" implicava três aspectos: a preparação física para o futuro; um equipamento (o lógos); e a maneira de ser.

${ }^{3}$ MUCHAIL, 2011, p. 106.

${ }^{4}$ GROS apud MUCHAIL, 2011, p. 105.

${ }^{5}$ FOUCAULT, 2008, p. 255. Foucault já havia analisado a maneira pela qual o sujeito constitui a si mesmo por meio do discurso verdadeiro (a confissão) em 1978, no curso Segurança, território e população, ao analisar as pastorais cristãs do século XIII, que consistiam em atividades religiosas exercidas por pastores que eram procurados por pessoas que desejavam outras formas, meios, procedimentos de salvação para as suas almas que não as da instituição católica (a Europa central passava pelo feudalismo). A salvação da alma se dava por meio da confissão de segredos individuais e da obediência a uma série de condutas e crenças que produziam uma verdade individualizante, uma especificidade que o diferenciava dos demais (singularidade) por meio da confissão, da extração da verdade.

${ }^{6}$ FOUCAULT, 2011, p. 4.

${ }^{7}$ FOUCAULT, 2011b, p. 46: Termo analisado no curso Do governo dos vivos, 
em 1980. Aleturgia é uma derivação de alêthourguês, que designa alguém que diz a verdade, por sua vez alêthourgia "poder-se-ia chamar a manifestação da verdade [...], um conjunto de procedimentos possíveis, verbais ou não, pelos quais se atualiza isso que é colocado como verdadeiro por oposição ao falso, ao oculto, ao invisível, ao imprevisível etc.".

${ }^{8}$ Fazemos uso dos textos Íon, de Eurípedes, História da guerra do Peloponeso, de Tucídides, Discurso sobre a paz, de Isócrates, as cartas Ve VII, A república e Górgias, de Platão.

${ }^{9}$ EURÍPIDES, 1994, p. 74. "Dou-te o nome de Íon, apropriado ao teu destino, porque foste tu o primeiro a vir ao meu encontro quando eu saía do templo do deus".

${ }^{10}$ EURÍPEDES apud FOUCAULT, 2010, p. 93-95. O filósofo observa no texto As suplicantes de Eurípedes um melhor arranjo em três categorias do que seria essa hierarquia: os tôn mèn adýnaton (próximo dos impotentes), os que não contribuem para a cidade; os khrestoí (pessoas de bem) e dynámenoi (podem alguma coisa), aqueles que possuem meios para exercer o poder, mas não se ocupam da política, a essa categoria também pertencem os sophós, os sábios que manejam o lógos; por fim, os logíon te khroménon te têi pólei (se serve de, ocupar-se de) são a autoridade política, aqueles que se servem tanto do logos como da pólis.

${ }^{11}$ EURÍPEDES apud FOUCAULT, 2010, p. 69.

${ }^{12}$ EURÍPIDES, 1994, p. 115. Em suma, na peça a verdade é manifestada pela deusa Atenas que, por sua vez, a revela a Creusa que a conta a Íon para que saiba do que tem direito e do que deve calar, dizendo-o: "Não é teu pai nenhum dentre os mortais, filho, mas aquele que te alimentou, o senhor Lóxias [Apolo]" (Lóxias significa oblíquo ou equívoco, devido à postura do deus nesta peça). Íon decide guardar silêncio para Xuto da verdade, acedendo assim aos primeiros da cidade.

${ }^{13}$ FOUCAULT, 2010, p. 69.

${ }^{14}$ FOUCAULT, 2010, p. 146.

${ }^{15}$ Ibidem, p. 148.

${ }^{16}$ EURÍPIDES, 2012, versos 448-453. Fedra diz amar outro (Hipólito, seu enteado) e não seu marido, Teseu, maculando assim a família pela simples confissão de tal desejo (Fedra faz tal confissão a sua escrava). O direito à parresía é então retirado dos filhos de Fedra, que diz: "Ah! Possam os meus filhos, livres e ufanos da sinceridade [segundo Foucault, o termo parresía 
é aqui usado], prosperar, orgulhosos da mãe, na gloriosa Atenas! Por mais altivo que seja seu coração o homem é escravo quando tem noção das faltas cometidas pela mãe ou pai".

${ }^{17}$ FOUCAULT, 2010, p. 148.

${ }^{18}$ Ibidem, p. 153.

${ }^{19}$ FOUCAULT, 2010, p. 153. Foucault alerta para a possibilidade de um erro de tradução no uso do termo parresía neste trecho, o que não nos impede de chamarmos atenção para o tipo de compreensão desse termo que ele está configurando ou querendo estabelecer, de modo que Foucault alerta para um erro de tradução pelo sentido não convergir para a noção que ele está tentando configurar.

${ }^{20}$ EURÍPEDES apud FOUCAULT, 2010, p. 153.

${ }^{21}$ TUCÍDIDES, 2001, p. 83.

${ }^{22}$ Foucault chama, até esse ponto, democracia de politeía, porém ele nota que Platão usa o termo politeía para nomear a constituição da cidade, seja democrática, oligárquica ou monárquica, e se adéqua a este uso. De todo modo, vamos acompanhando o desenvolvimento do filósofo.

${ }^{23}$ TUCÍDIDES, 2001, p. 121, grifo nosso.

${ }^{24}$ FOUCAULT, 2010, p. 152. Foucault chama de pacto parresiástico a relação em que, para governar, o soberano aceita certas verdades dos governados, assim como expõe certas verdades para os governados devido às dificuldades do percurso preterido, caso este de Péricles.

${ }^{25}$ ISÓCRATES, 2007, p. 238.

${ }^{26}$ FOUCAULT, 2010, p. 172.

${ }^{27}$ Ibidem, p. 177.

${ }^{28}$ Ibidem, p. 179.

${ }^{29}$ PLATÃO, 2001, 557 a.

${ }^{30}$ PLATÃO, 2001, 557 b: "Pois não serão em primeiro lugar pessoas livres, e a cidade não estará cheia de liberdade e do direito de falar, e não haverá licença de aí fazer o que se quiser?"

${ }^{31}$ Ibidem, $557 \mathrm{~d}$.

${ }^{32}$ Ibidem, 322 a, grifo nosso.

${ }^{33}$ Ibidem, 321 d-e.

${ }^{34}$ FOUCAULT, 2010, p. 195.

${ }^{35}$ FOUCAULT, 2010, p. 196.

${ }^{36}$ PLATÃO, 2007, 329 c: "Dionísio acusou Dião de conspirar contra a tirania, meteu-o numa pequena embarcação e o baniu ignomiosamente". 
${ }^{37}$ Ibidem, $324 \mathrm{c}$-d. O governo dos Trinta sucedeu a democracia ateniense, e consistiu, nas palavras de Platão, no arranjo "como chefes de governo de cinquenta e um cidadãos, onze dos quais ficaram na cidade e dez no Pireu, para dirigirem, respectivamente, a ágora e administrarem as duas localidades; os outros trinta foram investidos com autoridade suprema e poder absoluto".

${ }^{38}$ Ibidem, 325 a. O cidadão foi Leão de Salamina e Sócrates se recusou.

${ }^{39}$ Ibidem, 326 a.

${ }^{40}$ Ibidem, 328 a-b.

${ }^{41}$ Ibidem, $328 \mathrm{c}$.

${ }^{42}$ PLATÃO apud FOUCAULT, 2010, p. 202.

${ }^{43}$ PLATÃO, 2007, 105 d-e. Apesar da diferença entre instruir um soberano e instruir alguém que almeja a soberania, Foucault relaciona a situação Platão/ Dion com a de Sócrates/Alcibíades, em que, apesar da ascendência familiar e ambição de Alcibíades, Sócrates o diz: "Assim como pretendes demonstrar à cidade que és digno das maiores honrarias para de pronto alcançares o poder absoluto sobre ela, eu também, do meu lado, espero provar-te que te sou indispensável, e de tal forma indispensável que nem o teu tutor, nem teus parentes, nem ninguém mais se encontra em condições de entregar-te em mãos o poder que tanto ambicionas, senão eu somente".

${ }^{44}$ Ibidem, $330 \mathrm{~d}$.

${ }^{45} \mathrm{Idem}, 2010,720 \mathrm{c}$.

${ }^{46}$ Ibidem, $720 \mathrm{~d}$.

${ }^{47}$ Idem, 2007, 330 e.

${ }^{48}$ Ibidem, 330e-331a: "Quando o governo avança no caminho indicado pelas instituições e solicita algum parecer sobre questões de utilidade pública, é dar prova de cordura executar o que eles pedem. As cidades que se afastam inteiramente das instituições sadias e se recusam em absoluto a seguir-lhes as pegadas, [como a] ordenarem aos conselheiros que deixem a constituição tranquila e não a tirem do lugar, sob pena de morte se tal fizerem, e só desejem que todos se dobrem a seus caprichos e paixões e lhes indiquem meios mais rápidos e fáceis de satisfazê-los no futuro: consideraria desbriado quem se sujeitasse a dar conselhos em semelhantes condições”.

${ }^{49}$ FOUCAULT, 2010, p. 208.

${ }^{50}$ PLATÃO, 1980, 481 b. No Górgias, Sócrates pergunta a Polo qual a utilidade 
da retórica, dizendo a este que o discurso retórico não possui utilidade "para quem não se dispõe a praticar a injustiça", pois a retórica estaria baseada no desvio da injustiça em vez do não cometimento de injustiça. Por exemplo: o indivíduo que comete determinado crime e está sob julgamento, fará uso do discurso retórico para provar sua inocência, para desviar-se da injustiça cometida fazendo os juízes tomarem a imitação como real. Desse modo Sócrates diz que o importante é não cometer injustiças, em vez de tentar se desviar delas.

${ }^{51}$ FOUCAULT, 2010, p. 336.

${ }^{52}$ PLATÃO, 1980, 481 d: "Cálicles, se não houvesse entre os homens identidade de sentimentos, comuns a todos, embora com diferenças individuais, não seria fácil a ninguém explicar aos outros o que se passa consigo mesmo". Em certa medida, a retórica trabalha em uma instituição ou reinstituição da diferença, ainda que, a semelhança apontada por Sócrates em relação a Cálicles tenham sido suas duplas paixões: a de Sócrates por Alcibíades e pela filosofia; e a de Cálicles por Demo, filho de Pirilampo, e pelo demo ateniense (organização democrática).

${ }^{53}$ Idem, 2007, 331 c-d. Quando o filósofo chega a uma cidade para aconselhar, "se achar que [a cidade] está sendo malgovernada, pode falar, porém, só na hipótese de não fazê-lo inutilmente e de não arriscar a vida, e sem recorrer à violência para mudar a constituição local".

${ }^{54}$ FOUCAULT, 2010, p. 338.

${ }^{55}$ FOUCAULT, 2010, p. 338.

${ }^{56}$ Idem.

${ }^{57}$ PLATÃO, 2007, 340 b: "Ao chegar, meu primeiro cuidado foi certificar-me se Dionísio era mesmo unha e carne com a filosofia", sendo comum encontrar indivíduos que "se entopem de expressões filosóficas mal compreendidas, como era o caso de Dionísio, o que percebi tão logo desembarquei”.

${ }^{58}$ Ibidem, 340 b-e.

${ }^{59}$ PLATÃO apud FOUCAULT, 2010, p. 217.

${ }^{60}$ FOUCAULT, 2010, p. 217.

${ }^{61}$ FOUCAULT, 2010, p. 221.

${ }^{62}$ Ibidem, p. 311.

${ }^{63}$ FOUCAULT, 2011, p. 42.

${ }^{64}$ Idem. 
${ }^{65}$ ARISTÓTELES, 2006, p. 107. Essa “definição não se revelaria falsa se houvesse mais ricos do que pobres e fosse a maioria ricos que governasse ou, ao contrário, sendo eles superiores em número, fossem governados por um número menor de pobres? [...] Se são os ricos que comandam, será sempre a oligarquia, se são os pobres, a democracia”.

${ }^{66}$ Foucault usa o termo utilizado por Aristóteles, politeía, embora haja tradução para o português como regime constitucional e república, ainda que prefiramos politeía em nosso trabalho.

${ }^{67}$ ARISTÓTELES, 1998, 1277 a-b. Segundo Aristóteles, a virtude em um governante não é a mesma de um governado, assim como em um grupo de marinheiros virtuosos, a virtude é diferente em cada um dos marinheiros do grupo. Aristóteles concebe a virtude como possível em qualquer indivíduo, independente de pobre ou rico, assim como a temperança e o senso de justiça necessários para ser um governante.

${ }^{68}$ FOUCAULT, 2011, p. 44.

${ }^{69}$ ARISTÓTELES, 1998, 1279 b.

${ }^{70}$ Idem.

${ }^{71}$ Idem.

${ }^{72}$ Idem. A título de esclarecimento: politeía é o governo de muitos em favor do bem comum. Portanto, o que caracteriza a democracia é não necessariamente um governo de muitos, mas o governo em função dos pobres, ou mesmo um governo dos pobres e para os pobres, e não do bem comum.

${ }^{73}$ FOUCAULT, 2011, p. 46.

${ }^{74}$ FOUCAULT, 2011, p. 55.

${ }^{75}$ PLATÃO, 2007, 330 b.

${ }^{76}$ Ibidem, $330 \mathrm{c}$.

${ }^{77}$ Ver nota 56 do presente trabalho.

${ }^{78}$ ISÓCRATES, 1998, p. 34-35.

${ }^{79}$ FOUCAULT, 2011, p. 57.

${ }^{80}$ Idem.

${ }^{81}$ Ibidem, p. 58.

${ }^{82}$ Idem.

${ }^{83}$ Idem. 


\section{REFERENNCIAS}

ARISTÓTELES. Política. Tradução Antônio Campelo Amaral; Carlos de Carvalho Gomes. Lisboa: Vega, 1998.

ARISTÓTELES. A política. Tradução Roberto Leal Ferreira. São Paulo: Martins Fontes, 2006.

EURÍPIDES. Íon. Tradução Frederico Lourenço. Lisboa: Colibri, 1994.

EURÍPIDES. Tragédia grega: Medéia, Hipólito, as troianas. Tradução Mário da Gama Cury. Rio de Janeiro: Jorge Zahar, 2012.

FOUCAULT, Michel. Hermenêutica do sujeito. Tradução Márcio Alves da Fonseca; Salma Tannus Muchail. São Paulo: Martins Fontes, 2006.

FOUCAULT, Michel. Segurança, território e população. Tradução Eduardo Brandão. São Paulo: Martins Fontes, 2008.

FOUCAULT, Michel. O governo de si e dos outros. Tradução Eduardo Brandão. São Paulo: Martins Fontes, 2010.

FOUCAULT, Michel. O governo de si e dos outros II: a coragem da verdade. Tradução Eduardo Brandão. São Paulo: Martins Fontes, 2011.

FOUCAULT, Michel. Do governo dos vivos: curso no Collège de France, 1979-1980. Tradução Nildo Avelino. São Paulo: Centro Cultural Social; Rio de Janeiro: Achiamé, 2011b. 
ISÓCRATES. Nicoclés. In: ISÓCRATES; PLATÃO; KAUTILYA et al. Tradução Jean-François Cleaver. Conselhos aos governantes. Brasília: Senado Federal, 1998. p. 27-46.

ISÓCRATES. Discursos. Tradução Juan Manuel Guzmán Hermida. Madrid: Gredos, 2007.

MUCHAIL, Salma Tannus. Foucault, mestre do cuidado: textos sobre a hermenêutica do sujeito. São Paulo: Loyola, 2011.

PLATÃO. Diálogos: Protágoras, Górgias, o banquete, Fedão. Tradução Carlos Alberto Nunes. Belém: UFPA, 1980.

PLATÃO. A república. Tradução Maria Helena da Rocha Pereira. Lisboa: Fundação Calouste Gulbenkian, 2001.

PLATÃO. Diálogos: Fedro, cartas, primeiro Alcibíades. Tradução Carlos Alberto Nunes. Belém: EDUFPA, 2007.

PLATÃO. As leis. Tradução Edson Bini. São Paulo: EDIPRO, 2010.

TUCÍDIDES. História da guerra do Peloponeso. Tradução Mário da Gama Kury. Brasília: UNB; São Paulo: Imprensa Oficial, 2001.

ENVIADO EM: 04/03/2016 APROVADO EM: 23/05/2016 